\title{
VEVŐ - beszállító kapcsolatok és jellemzőik az autóiparban
}

\section{Customer and supplier relationships and their characteristic in the automotive}

\author{
K. MORAUSZKI ${ }^{1}$, A. LAJOS ${ }^{2}$ \\ ${ }^{1}$ Szent István Egyetem, Gazdálkodás és Szervezéstudományok Doktori Iskola, morauszki.kinga@gtk.szie.hu \\ ${ }^{2}$ Szent István Egyetem, Gazdálkodás és Szervezéstudományok Doktori Iskola, lajos.attila@gtk.szie.hu
}

Absztrakt. A szerzők különböző hazai és nemzetközi háttérirodalom feldolgozásával adnak rövid áttekintést arra vonatkozóan, hogy milyen kapcsolattípusokról beszélhetünk az autóiparban. Melyek azok a formák, amelyeket a felek jobban preferálnak, elterjedtebbek, továbbá milyen megkülönböztető jegyeket viselnek az egyes kapcsolati formák. A vevő - beszállító kapcsolatok alapvető kérdése, hogy a vevők miként kezelik beszállítóikat, mint partnereiket. A beszállítói kapcsolat akkor igazán értékes, ha nem csak egyszerú termékszállításról beszélünk, hanem pozitív partnerkapcsolat alakul ki a két fél között. A tanulmány célja egy irodalmi áttekintés, mely a kutatási témakör elméleti alapjait hivatott összefoglalni, ezáltal egyfajta kiinduló pontot jelent a gyakorlati alkalmazás során.

Abstract. This article gives short review with the help of specialized literature that was written both national and overseas. This gives information about whatrelationships can you speak in the automotive.This study briefly presents what are the forms which are preferred by the companies, they are more general and what distinctive characteristics do the forms of contact have. Essential question of the customer-supplier relationships is the following - how does the customer company treat its supplier as a partner. The supplier relationship is very precious if we are not talking only about easy product-delivery but a positive relationship can be developed between the two sides. The aim of this study is a literature review which has summarized the theoretical ground of this subject, so that means a kind of a starting point in the practice.

\section{Bevezetés}

A „kapcsolat” szó olyan gondolatokat ébreszt két ember között, mint a kölcsönös vonzalom és tisztelet, megfontolás, függőség, stb. Ezek olyan tényezők, amelyek csak akkor jelennek meg, ha a feltételek teljesültek. Időszakos kölcsönhatást jelent két vagy több személy között (HINDE, 1979). POEISZ és RAAIJ (1993) ezt a következőben részletesebben leírja:

- Kölcsönhatás legalább két fél között jön létre, ahol az egyik fél tevékenysége befolyásolja a másikat és fordítva. 
- Egy bizonyos fokú folytonosság jelen kell, hogy legyen a kapcsolatban, hiszen a múltbéli kölcsönhatások befolyásolják a jelen és a jövő kölcsönhatásait; a kapcsolatokat hosszú távon kell kiterjeszteni.

- A kölcsönhatások hatásai függnek a jelenlegi eseményektől.

Egy kicsit távolabbról megközelítve a témakört a pszichológia területén belül megkülönböztetnek elsődleges és másodlagos kapcsolatokat. Az első kapcsolattípus hosszútávra szóló, személyek közötti kapcsolatot ír le, amely elsősorban érzelmi kötödésekre és kölcsönös kötelezettségre épül. Itt a kapcsolat szereplői könnyebben helyet tudnak cserélni (SMIT et al., 2007). A másodlagos kapcsolatok, mint például vevő és beszállító között, viszonylag rövid távú kapcsolatok korlátozott szociális kölcsönhatással; meglehetősen egyértelmű etikett-szabályok és jól meghatározott társadalmi szerepek jellemzik. Az elsődleges és másodlagos kapcsolatok átmeneti zónája meglehetősen nagy (PEELEN, 2005). Az autóipar manapság a legfontosabb iparágnak számít a világon az újítások és a munkahelyek tekintetében. Az autóipar autógyárakból, azaz ún. OEM ${ }^{1}$-ekből (Original Equipment Manufacturer) áll, mint pl. a BMW, Ford, Daimler és Volkswagen, illetve beszállítókból, mint a Continental, ZF, és a Bosch. Az autóipar sajátossága befolyást gyakorol az autógyárak és beszállítóik közötti kapcsolatra. Csak az ún. első szintű beszállítók lépnek közvetlen kapcsolatba az OEM-kkel (HUNDERTMARK, 2013).

\section{Hagyományos és újszerű kapcsolatok felépítése}

Az utóbbi években az autógyárak (továbbiakban OEM-k) és a beszállítók közötti kapcsolatok változáson mentek keresztül. Többek között a 2008/2009-es gazdasági válság is hatalmas befolyással bírt. Az ORM (OEM Relationship Management) egy stratégiai és operatív kapcsolatot ír le a beszállító és az OEM között. Ez magába foglalja a konkrét intézkedéseket, hogy igazodjanak az OEM-k mindenkori szerkezetéhez, sajátosságaihoz, igényeihez. Az ORM előnyös, ha kölcsönös függőség áll fenn az üzleti partnerek között, illetve a vásárlói döntés fokozott kockázatot hoz magával. A megnövekedett vizsgálódások alapján megkülönböztethetünk egy hagyományos, és talán nem teljesen új, de újszerű vevő-beszállítói kapcsolatot. A két koncepció közötti különbség mindenekelőtt a játékszabályokban rejlenek, illetve az együttmúködés milyenségében, azonban a teljesítmények nagyságrendje megoszlik a gyártók és beszállítóik között.

${ }_{1}^{1}$ OEM (Original Equipment Manufacturer) - autóipari összeszerelő üzemek 


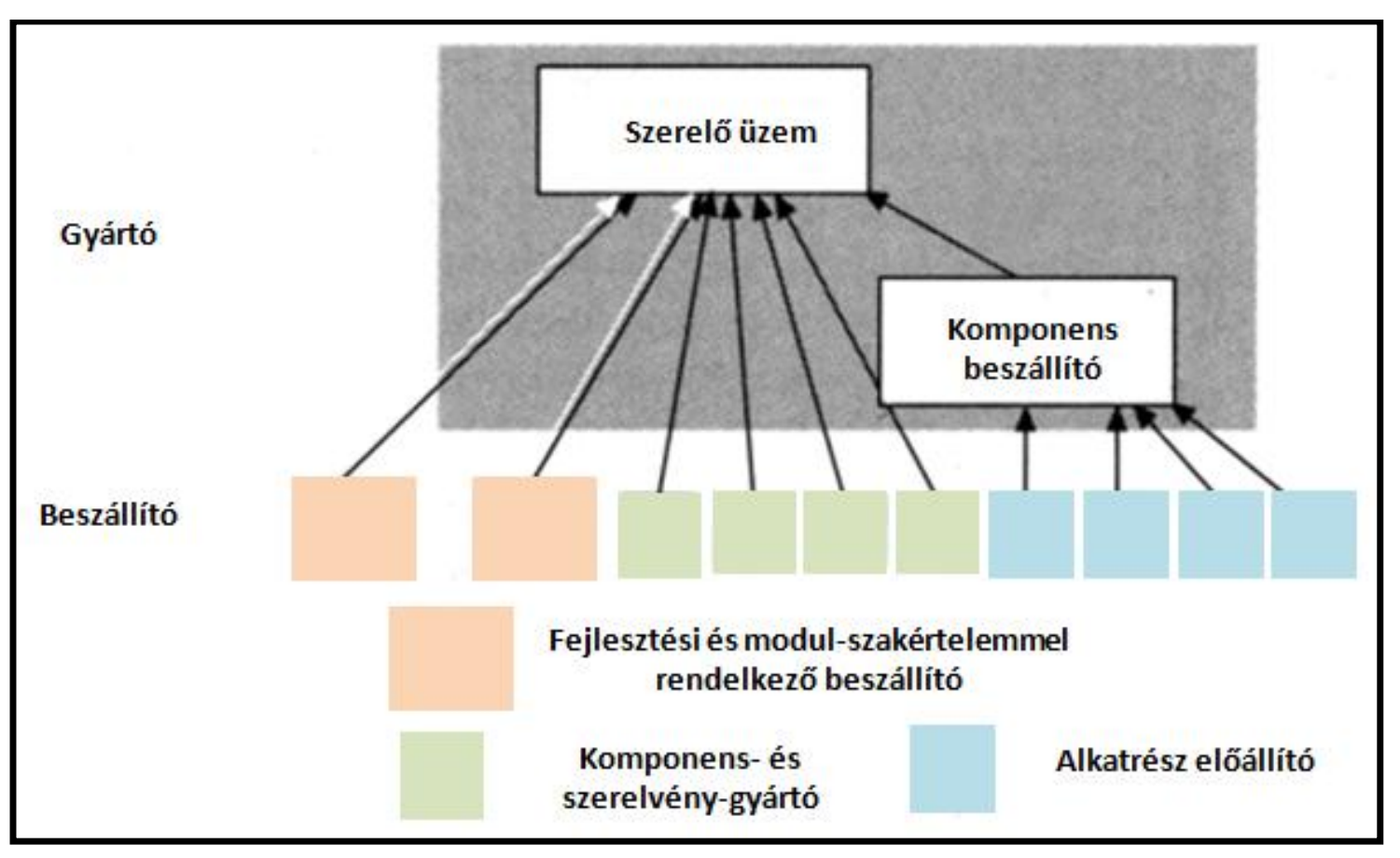

1. ábra: A hagyományos vevő-beszállítói kapcsolatok felépítése

(Forrás: http://www.daswirtschaftslexikon.com alapján saját fordítás, 2015)

A hagyományos szemlélet a klasszikus vevő-beszállító kapcsolatra épül, két üzleti partner között, melyet alacsony együttműködési szint jellemez. A hagyományos esetben a végtermék előállítónak csak kevés beszállítója van fejlesztési- és modul-szakértelemmel. A gyártó számos komponens-, szerelvényés alkatrész-beszállító szállításait koordinálja, így ennek megfelelően jelentős komplexitást kell leküzdenie a beszerzési oldalon (1. ábra). Éppen ezért a gyártó vállalatnak a részletes szerződések és QSV-k (Qualitätssicherungsvereinbarungen)² ellenére ez magas tranzakciós költséget okoz, amelyeket a magas logisztikai költségek is igazolnak, és nem utolsó sorban fontos szem előtt tartani, hogy nagy a ráfordítás a minőségügyi auditokra és certifikációkra is.

Így összességében elmondhatjuk, hogy a hagyományos kapcsolatban az ár a döntő tényező, és ez alapján választja ki a vevő vállalat a potenciális beszállítókat, akiket megversenyeztet egymással, így a lehető legalacsonyabb árat érheti el. A napjainkban elterjedt újszerű vevő-beszállító kapcsolat koncepciója (2. ábra) a Lean menedzsment elveire épül. Ezen koncepció teljesen más játékszabályt vesz alapul, mint a hagyományos megközelítés, és mindenekelőtt a folyamatos javításra, fejlesztésre, illetve teljesítmény-alapú együttműködésre összpontosít ${ }^{3}$. Az új szemléletű vevő-beszállító kapcsolat során azonban a gyártó vállalat (OEM) viszonylag kevés, közvetlen beszállítóval érintkezik, akik viszont mint fővállalkozó irányítják a többi komponens- és al-beszállítókat. Ezt a megoldást már évek óta alkalmazzák (FIETEN, 1981). Ez a koncepció vezet a beszállítói piramis kialakulásához.

\footnotetext{
${ }^{2}$ Qualitätssicherungsvereinbarung $(Q S V)$ - minőségügyi megállapodások, mely a vevő és a beszállító között jön létre, amely a szállítandó termék minőségével kapcsolatos rendelkezéseket, szabályokat, munkamegosztást tartalmazza.

${ }_{3}^{3}$ Forrás: Zulieferer-Abnehmer-Beziehungen On-line: http://www.daswirtschaftslexikon.com/d/zulieferer-abnehmerbeziehungen/zulieferer-abnehmer-beziehungen.htmLetöltés: 2013.08.08.
} 


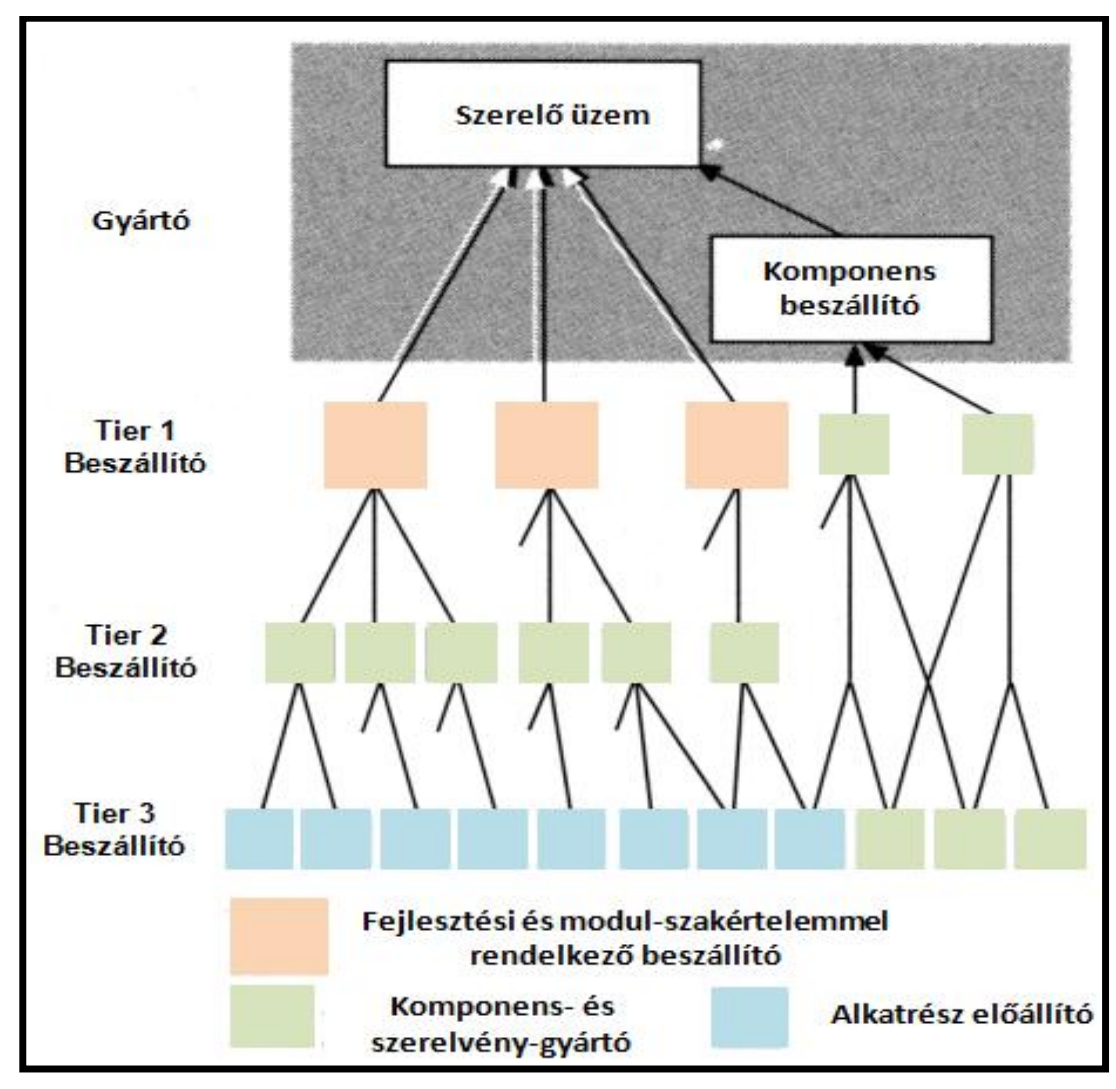

2. ábra: A vevő-beszállítói kapcsolat újszerû́ megközelítése

(Forrás: http://www.daswirtschaftslexikon.com alapján saját fordítás, 2015)

\section{Kapcsolattípusok}

A vállalatok egyre inkább a stratégiai partnerekre kezdenek összpontosítani a gyártási folyamatok során, és elismerik az ellátási lánc és ellátási lánc menedzsment jelentőségét annak érdekében, hogy képesek legyenek megbirkózni a környezeti változásokkal. Annak érdekében, hogy a piacon versenyképes előnyt szerezzenek, a gyártóknak együtt kell működniük, nem csak az alkatrész vagy nyersanyag beszállítókkal, hanem a nagy- és kiskereskedőkkel, forgalmazókkal, azaz mindenkivel, aki közvetve vagy közvetlenül, de részt vesz az ellátási láncban, hogy a vevői követelményeket, kéréseket kielégítsék. A gyártóknak ki kell választani a különböző lehetséges beszállítók közül a legegyüttműködőbbet, aki képes hosszú távú kapcsolat kialakítására (SUNG HO HA et al., 2009). Különösen a beszerzési tevékenységek játszanak stratégiai szerepet, azaz a helyi beszerzéstől kiindulva a hosszú távú szerződéses kapcsolatokig. Ìgy a beszállítók kiválasztása stratégiai döntéssé vált, ami azt jelenti, hogy fontos forrássá vált a gyártók versenyképességének fejlesztésében (WISE és MORRISON, 2000). A beszállítói kapcsolat akkor igazán értékes, ha nem csak egyszerű termékszállításról beszélünk, hanem ezen túlnőve mindkét fél számára megfelelő, pozitív partnerkapcsolat alakul ki a két fél között. A vevő - beszállító kapcsolatok alapvető kérdése, hogy a 
vevők miként kezelik beszállítóikat. Két alternatíva is él egymás mellett a gyakorlatban (SZARKA, 2002).

\section{1. Versenyeztető modell, azaz több beszállítótól való beszerzés (Multi- Sourcing)}

Az ár az a szempont, melynek alapján a vevők kiválasztják azokat a beszállítókat, akik a legalacsonyabb áron tudnak szállítani. A legalacsonyabb árat pedig úgy lehet elérni, ha szállítóikat versenyeztetik egymással, ezáltal versenyhelyzet alakul ki. Ez a megközelítés a beszállítót ellenfélként kezeli. A felek közötti együttmúködés alapvetően a minimálisan szükséges információcserére és fizikai folyamatokra korlátozódik (ár, mennyiség, minőség, szállítási határidők, stb.), s a felek mindegyike saját céljai megvalósításában érdekelt, amelyet nem hangolnak össze. A kommunikáció jellemzően egyoldalú, $\mathrm{s}$ az esetlegesen fellépő konfliktusokat jogi úton igyekeznek rendezni. Hátrányként említhetők, hogy magas állandó költséggel kell számolni, mivel minden egyes beszállítóhoz kapcsolódóan kell kialakítani a logisztikai rendszert (PINTÉR, 2010).

\section{2. Együttműködési modell, azaz egy beszállítótól való beszerzés (Single- Sourcing)}

Az együttműködésre helyezi a hangsúlyt, ahol a cél a vállalati versenyképesség javítása. A vállalati célok elérését leginkább az szavatolja, ha a beszállítók száma minél kisebb, velük viszont olyan kapcsolatot alakítunk ki, amely együttműködésen alapszik. A felek a közöttük zajló folyamatok összehangolására törekszenek, s közös célokat fogalmaznak meg. A fellépő potenciális konfliktusokat tárgyalásos úton próbálják rendezni. Egy vállalat számára fontos az ellátás biztonsága, melynek biztosítása egyszerűbb, ha kevesebb beszállító van. Előnyként említhetjük, hogy tartós partneri kapcsolat jöhet létre. E beszerzési típus hátránya azonban a beszállítótól való nagyfokú függőség (PINTÉR, 2010). Összességében elmondható, hogy a kapcsolat jellegét tekintve (3. ábra) az együttműködési modellt alkalmazva, a vállalatok inkább partnernek tekintik a beszállítót, és az esetlegesen felmerülő problémákat igyekeznek közösen megoldani, míg a másik modell alkalmazása során a beszállítót ellenfélnek tekintik. Ennek következménye az is, hogy a vevők sok esetben bizalmatlanok beszállítóik felé. Lássuk be, ez semmi jót nem eredményezhet, és mégis vannak olyan vállalatok, akik alkalmazzák ezt a modellt. 


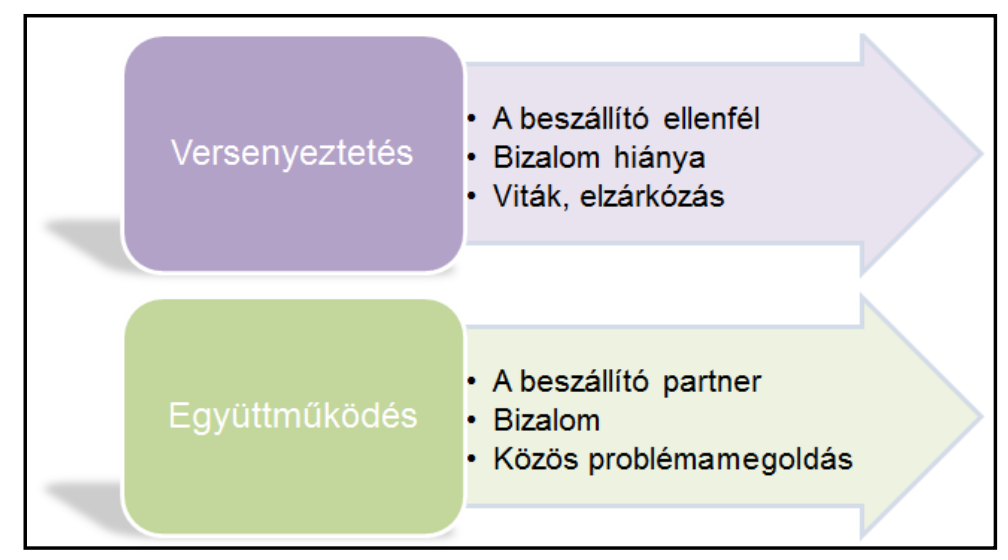

3. ábra: Vevő - beszállító kapcsolatok jellege

(Forrás: Saját szerkesztés, 2012)

A vállalatok azonban előszeretettel alkalmazzák egyszerre a két modellt. A következő összefoglaló táblázat a különbségeket mutatja be a vevő - beszállító kapcsolatokra vonatkozóan (1. táblázat).

\begin{tabular}{|l|l|l|}
\hline Versenyeztető modell & Tulajdonságok & Együttműködési modell \\
\hline Sok & Szállítók száma & Egy vagy kevés \\
\hline Egyszeri, rövid & Kapcsolat hossza & Közép, hosszú táv \\
\hline Nincs & Közös tevékenység & Lényeges \\
\hline Elkülönül & Termelés, tevékenység & Összekapcsolt \\
\hline Alkalomszerű & Rendelés & Gyakori kis tétel \\
\hline Győztes - vesztes & Tárgyalási stratégia & Mindkét fél számára előnyös \\
\hline Versenyeztetés & Szállító kiválasztása & Tárgyalás \\
\hline
\end{tabular}

1. Táblázat: Vevő - beszállító kapcsolatok két típusa stratégiai szempontból

(Forrás: SZARKA, 2002)

A beszerzők leginkább azokat a beszállítókat részesítik előnyben, amelyek nyereségesek, mert ezek érdekeltek a határidőre történő szállításban. A többi beszállítónak esetlegesen gondot okozhat az „alapanyagok” beszerzése, ami minden bizonnyal hatással lehet a szállítási időre, illetve a termékek minőségére is. Az első modell esetében a megrendelést az kapja, aki a legalacsonyabb árat ajánlja. Az együttműködés során a vevő viszont számos előnyt vár szinte minden területen (2. táblázat). 


\begin{tabular}{|c|c|c|c|}
\hline Beszerzés & Műszaki előnyök & Pénzügyi előnyök & Minőség \\
\hline $\begin{array}{l}\text { Tervek összehangolása; } \\
\text { Gyakori kommunikáció } \\
\rightarrow \text { igények egyeztetése; } \\
\text { Probléma fellépésekor } \\
\text { nagyobb figyelem } \\
\text { egymásra; } \\
\text { Kisebb beszállítói } \\
\text { bázist könnyebb } \\
\text { menedzselni }\end{array}$ & $\begin{array}{l}\text { Beszállító } \\
\text { bevonása a } \\
\text { termékfejlesztésbe } \\
\text { a termék } \\
\text { minőségét javítja, } \\
\text { és meggyorsítja az } \\
\text { új termék } \\
\text { kifejlesztésének } \\
\text { idejét }\end{array}$ & $\begin{array}{l}\text { Kockázatcsökkentés; } \\
\text { Költségcsökkentés; } \\
\text { Alacsonyabb árak; }\end{array}$ & $\begin{array}{l}\begin{array}{l}\text { Lehetőség van } \\
\text { folytonos } \\
\text { fejlesztésre; }\end{array} \\
\text { A folyamatok } \\
\text { minőségére nagyobb } \\
\text { figyelem esik; }\end{array}$ \\
\hline
\end{tabular}

2. Táblázat: Az együttmúködési modellből származó előnyök

(Forrás: Saját szerkesztés, 2012)

Ahhoz, hogy a vevő-beszállító kapcsolat szorosabbá váljon, több út is létezik. Egyrészt a beszállítók számának a csökkentésében látják az egyik megoldást. A vállalatok előszeretettel hoznak létre ún. minősített beszállítói státuszt, melynek értelmében a vevő vállalatok csak azoktól a beszállítóktól rendelnek, amelyek rendelkeznek ilyen státusszal. Másodsorban, ha a vevő vállalat megtalálta a számára legmegfelelőbb beszállítókat, akkor igyekszik azt a kapcsolatot hosszabb távon is fenntartani, azaz a kapcsolat időtartamát növelni, amelyre a legjobb példa a keretszerződések kialakítása. Ez esetben nem lesz szorosabb a két fél között létrehozott kapcsolat, de hosszú távra fog szólni. Ezen szerződések egyik oka az ellátás folyamatosságának biztosítása, vagy a beszerzési költségek csökkentése. Ezeket a kapcsolatokat külső és belső faktorok (piaci erőviszonyok, vállalati méret, beszállítók felkészültsége, stb.) is egyaránt befolyásolják. Így az egyes beszállítókkal való viszony nem egyforma. A 3. táblázat a különböző beszállítói kapcsolatokat mutatja be. Az 1. táblázattal ellentétben, ahol stratégiai szempontból csoportosítottuk a beszállítói kapcsolatokat, négy jellegzetességről beszélhetünk, ami alapján történt a felosztás. Ez pedig a termék, ipar / piac, beszállító és a függőség a vevői részről (BENSAOU, 1999). 


\begin{tabular}{|c|c|c|c|c|}
\hline JELLEGEZETESSÉG & VERSENYZÖ & EGYÜTTMƯKÖDŌ & „FOGOLY” & IRÁNYÍTó \\
\hline Termék & $\begin{array}{l}\text { - standardizált termék } \\
\text { - kevés innováció } \\
\text { - olcsó termék }\end{array}$ & $\begin{array}{l}\text { - komplex termék } \\
\text { - nagy beruházás } \\
\text { - magas } \mathrm{K}+\mathrm{F} \text { szükséglet }\end{array}$ & $\begin{array}{l}\text { - komplex termék } \\
\text { - kevés innováció } \\
\text { - kevés változás }\end{array}$ & $\begin{array}{l}\text { - komplex termék } \\
\text { - beszállító által fejlesztett új } \\
\text { technológia } \\
\text { - kevés innováció } \\
\text { - magas K+F szükséglet }\end{array}$ \\
\hline Ipar/piac & $\begin{array}{l}\text { - beszállítói piac } \\
\text { - fragmentált } \\
\text { - sok ajánló } \\
\text { - árverseny } \\
\text { - kevés növekedés }\end{array}$ & $\begin{array}{l}\text { - mindkét piac } \\
\text { - koncentrált } \\
\text { - növekedési piac } \\
\text { - magas kereslet }\end{array}$ & $\begin{array}{l}\text { - beszállítói piac } \\
\text { - koncentrált } \\
\text { - vevöi piac } \\
\text { (esetlegesen) } \\
\text { - stabil kereslet } \\
\text { - nincs növekedés }\end{array}$ & $\begin{array}{l}\text { - beszállitói piac } \\
\text { - fragmentált } \\
\text { - vevői piac } \\
\text { - koncentrált } \\
\text { - növekedési piac } \\
\text { - erős verseny } \\
\text { - instabil piac }\end{array}$ \\
\hline Beszállitó & $\begin{array}{l}\text { - a beszállító kisebb, mint a vevő } \\
-\quad \text { beszállító alacsony } \\
\text { alkupozícióval, de nagyobb } \\
\text { vevő̃i függőséggel }\end{array}$ & $\begin{array}{l}\text { - a beszállító szinte } \\
\text { ugyanolyan nagy, mint a } \\
\text { vevő vállalat } \\
\text { - magas kutatási } \\
\text { hozzájárulás a termékekhez }\end{array}$ & $\begin{array}{l}\text { - nagy beszállitó } \\
\text { - magas alkupozíció }\end{array}$ & $\begin{array}{l}\text { - kisebb, gyakran fiatal } \\
\text { vállalat saját technológiával } \\
\text { - alacsony alkupozíció }\end{array}$ \\
\hline
\end{tabular}

\section{Táblázat: Beszállítói kapcsolatok típusai}

(Forrás: BENSAOU alapján saját szerkesztés, 2014)

CLEMENTS és társai (2007) azt vallják, hogy a vállalatok számára igen fontos, hogy hosszú távon összehangolt és kooperatív kapcsolatokat építsenek ki más vállalatokkal. RINEHART és társai (2004) szerint hozzá tudnak járulni egy szoros együttműködéshez, hogy a termékköltségeket és a ráfordított időt csökkentsék, a termékminőséget, szervizt és a szállítást javítsák.

\section{3. Kapcsolatok jellemzői}

A beszállítókkal kialakított kapcsolatok milyensége és minősége, vagyis a kapcsolatmenedzsment a logisztikai, valamint a marketingcélok, és elvárások változásával egyre inkább kiemelkedő jelentőséggel bír. A beszállítói kapcsolatok típusait illetően SZEGEDI ès PREZENSZKI (2003) szerint az alábbi három modell a legjellemzőbb:

\section{Tranzakció orientált modell (hagyományos)}

Az árakat és a beszerzési tranzakciót helyezi előtérbe, célja a legalacsonyabb ár elérése és folyamatos ellátás biztosítása. Nem üzleti bizalomra épülő kapcsolat, ahol a vevő kihasználja hatalmi helyzetét. A beszállítót ellenfélként kezeli. A modell felépítése alapján csak egy nyertese lehet ezeknek a kapcsolatoknak. Rövidtávú, alkalomszerű kapcsolat jellemzi. A beszerzés fejlődésének korai szakaszában volt kedvelt.

\section{Kapcsolatorientált modell}

Szinte a leggyakoribb kapcsolattípus. Ebben az esetben a szállító kiválasztását tárgyalás, tenderek előzik meg. A beszerző a beszállítót üzleti partnerként kezeli, bizalmi kapcsolatban állnak. Közösen oldják meg a problémákat, jó az információáramlás közöttük. Kevés vagy csak egy beszállító alkalmazása esetén jellemző ez a modell, melynek alapján a cél, hogy mind a két fél nyertesnek kerüljön ki. Az egyes beszállítók információforrást is jelentenek egymás számára.

\section{Stratégiai partnerkapcsolat}


A változó technológiai előírások, a rövidebb termék-életciklus, valamint a gyártási mélység változása, és az erősödő piaci verseny kapcsán a stratégiai partnerkapcsolatok szerepe és száma megnőtt. Kölcsönösen előnyös, hosszabb távú együttműködés, mely során megvalósul a felek bizonyos mértékű tevékenységi integrációja. Lényeges a két fél összehangolt együttműködése, mivel komplex beszerzési feladatokat kell együttesen megoldaniuk. Gyakoribb kommunikáció szükséges, a felek egymásra vannak utalva. A kisebb beszállító kör (egy vagy két beszállító) könnyebben irányítható; kevesebb időt kell szentelni az új beszállítók felkutatatására (MAJOROS, 1998).

A fent említett 3 modell összefoglaló jellemzését az 4. Táblázat szemlélteti.

\begin{tabular}{|c|c|c|c|}
\hline & $\begin{array}{l}\text { TRANZAKCIÓ- } \\
\text { ORIENTÁLT }\end{array}$ & KAPCSOLATORIENTÁLT & $\begin{array}{l}\text { STRTÉGIAI } \\
\text { PARTNERKAPCSOLAT }\end{array}$ \\
\hline Célja & $\begin{array}{l}\text { Legalacsonyabb ár és a } \\
\text { folyamatos ellátás } \\
\text { biztosítása }\end{array}$ & $\begin{array}{l}\text { Mindkét fél „nyertesként“ } \\
\text { kerüljön ki }\end{array}$ & $\begin{array}{l}\text { Kölcsönösen } \\
\text { együttműködés }\end{array}$ \\
\hline Alapja & $\begin{array}{l}\text { Nem üzleti bizalomra } \\
\text { épül }\end{array}$ & Üzleti bizalomra épül & Üzleti bizalomra épül \\
\hline $\begin{array}{l}\text { Kapcsolat } \\
\text { hossza }\end{array}$ & Rövidtávú & Hosszú távú & Hosszú távú \\
\hline Alkalmazása & $\begin{array}{lr}\text { A } & \text { beszerzés } \\
\text { fejlődésének } & \text { korai } \\
\text { szakaszában } & \\
\text { alkalmazták } & \end{array}$ & Gyakori & Gyakori \\
\hline $\begin{array}{l}\text { Felek közötti } \\
\text { kapcsolat }\end{array}$ & $\begin{array}{l}\text { A vevő } \quad \text { igyekszik } \\
\text { kihasználni } \\
\text { pozícióját }\end{array}$ & $\begin{array}{l}\text { A beszállítót üzleti } \\
\text { partnerként kezelik }\end{array}$ & A felek egymásra vannak utalva \\
\hline
\end{tabular}

4. Táblázat Beszállító kapcsolatok összefoglaló táblázata

(Forrás: Saját szerkesztés, 2016)

A vevő-beszállító kapcsolatok alakíthatóak, azaz szorosabbá tehetőek, mivel a felek hosszú távon akarnak a „másikkal számolni”. Ennek alapján fontos, hogy a kapcsolatok mennyire szorosak. Ezt a beszerzendő termékek jellemzői is meghatározhatják, illetve a vállalati méret, piaci viszonyok, stb. A Kraljic-mátrix ennek megfelelően a termékeket osztályozta. A termék jellege alapvetően meghatározza a beszállítói kapcsolatok milyenségét, ezért használják fel a beszállítók kiválasztásának elemzésében a Kraljic mátrixot is. A beszerzési stratégia megválasztásában, a beszerzendő anyagok, áruk osztályozásában nyújt segítséget a Krajlic mátrix. A Kraljic szerinti osztályozás alapja, a beszerzés fontossága és a kockázata (5. Táblázat). A fontosság belső kockázat, az árura vonatkozó kiadás arányát viszonyítják a teljes beszerzési költséghez. A fontossága növekedhet az által, ha kulcstermék, vagy ha több termékhez is felhasználják, és mindezek által hiánya jelentős többletköltséggel járna. A beszerzés kockázata külső kockázatot jelent, a helyettesíthetőség, a beszállító, ill. a beszállítandó anyag piaci 
helyzete, a különböző árfolyam, politikai, vagy természeti kockázatok. Négy fő termékcsoportot különböztet meg:

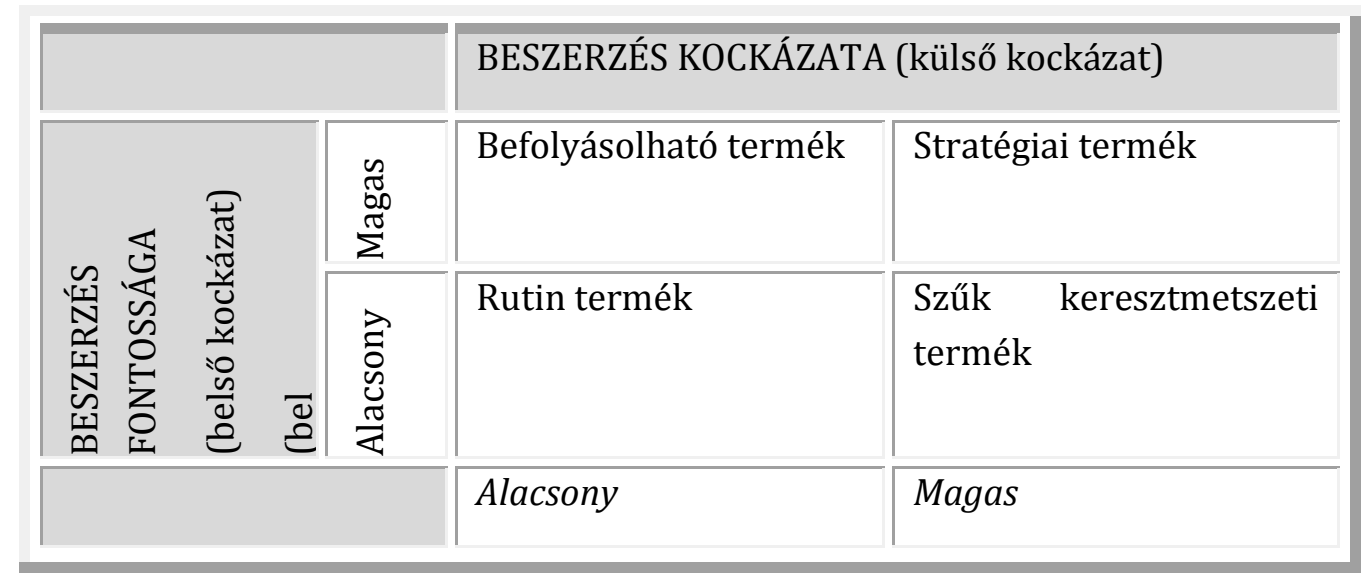

5. Táblázat Kraljic mátrix

(Forrás: CHIKÁN ès DEMETER, 1999)

1. Stratégiai termékek: Olyan termékek melyek szerepe kulcsfontosságú a vállalati működésben, rendszerint magas értékűek és beszerzése gyakran problémás, ezért ez esetben a stratégiai partnerkapcsolat kialakítása célszerü.

2. Szűk keresztmetszetű termékek: Közepesen nélkülözhető termékek, beszerzésük néha nehézségbe ütközik, vagy kevés beszerzési forrás. A partnerkapcsolat kapcsolatorientált típusa a jellemző.

3. Befolyásolható, vagy hatalmi termékek: A vállalat szempontjából fontos termék, azonban beszerzési kockázata alacsony, magas a beszerző alkuereje, a több beszállító, vagy a rendszerint nagy rendelési mennyiség miatt.

4. Rutintermékek, nem kritikus javak: Fontos, a müködéshez szükséges termékek, de alacsony a beszerzési kockázata, nem szükséges ezért az erőforrások lekötése, a tranzakció orientált beszállítói kapcsolat jellemző rá.

A mátrix segítségével a vállalatok a megfelelő beszerzési döntést tudják meghozni. Az adott vállalatnak először értékelnie kell a beszerzési javakat, majd a beszerzési piacokat, hogy felszínre kerüljenek a beszerzéssel kapcsolatos kockázatok. Ezt követően csoportokba tudják sorolni a termékeket, és meg határozhatják a beszerzési stratégiát. Végül utolsó lépésben az akcióterv kifejlesztésével zárul le a folyamat (ULKUNIEMI, 2003).

\section{Összefoglalás}

Az autóipar igen összetett és szerteágazó ágazat, amely folyamatosan változik, változott az évek, évtizedek során, és változni is fog. A változás magába foglalja mind a folyamatok (termelési folyamatok), mind pedig a termékek, termékskálák változását is; azaz ahogy változnak a vevői igények, úgy változik, úgy alakul az ipar is. Ezek a változások viszonylag gyorsan mennek végbe, ahol a folyamat minden szereplőjének bírnia és nem utolsó sorban tartania kell az iramot.

Sajnos vannak olyan beszállító vállalatok, akik erre nem képesek, vagy legalább is nem 100\%-ban. Ezek a vállalatok általában lemorzsolódnak az évek során, jönnek helyettük „újak”, akik majd 
bekapcsolódnak a körbe. A vevő vállalatok éppen ezért a legjobb, leggyorsabban változni, változtatni képes beszállító vállalatokkal próbálják körbe venni magukat, és igényeiket ő általuk kielégíteni. Ha már megvan a potenciális beszállító, aki minden téren eleget tud tenni a vevő igényeknek, kéréseknek, akkor a vevő vállalat inkább ezzel vagy ezekkel a beszállítókkal foglalkozik és építi a kapcsolatot, hogy hosszú távú erős alapokon álló üzleti partnerség alakuljon ki.

A tanulmány számos kapcsolattípust említ, mutat be (különböző értékelési tényezők alapján csoportosítva), amelyek mindegyikének meg vannak a maga előnyei és hátrányai. Minden esetben a felek a legjobbat akarják kihozni az adott üzletből, illetve az üzleti kapcsolatból, hogy abból majd hosszútávon tudjanak profitálni.

\section{Hivatkozások}

[1] B. M. Bensaou (1999), Portfolios of Buyer - Supplier Relationships, In: Operations Management and Research, Sloan Management Review, 40, No. 4, Summer pp. 35 - 44.

[2] A. Chikán, K. Demeter (1999), Értékteremtő folyamatok menedzsmentje, Aula Kiadó, Budapest, p.447.

[3] M. D. J. Clements, D. L. Dean, D. A. Cohen (2007), Proposing an Operational Classification Scheme for Embryonic Cooperative Relationships, Journal of Management and Organization, Vol. 13 (1), pp. 51-64.

[4] R. Fieten (1981), Beschaffungsplanung im industriellen Großanlagengeschäft, in: Organisation, Planung, Informationssysteme, hrsg. v. Frese, E./Schmitz, P./Szyperski, N., Stuttgart, p. 137.

[5] Hinde (1979), Towards understanding relationships, Published in cooperation with European Association of Experimental Social Psychology by Academic Press, University of Michigan

[6] H. Hundertmark (2013), Beziehungs management in der Automobilindustrie: OEM Relationship Management als Sonderfall des CRM, Springer Gabler, Wiesbaden, pp. 105124.

[7] P. Majoros (1999), Iparvállalatok beszerzésgazdaságtana, Múszaki Könyvkiadó, Budapest, pp. 32-53.

[8] E, Peelen (2005), Customer Relationship Management, Pearson Education Limited, England, pp. 25-28.

[9] R. Pintér (2010), Értékteremtő folyamatok menedzsmentje, Beszerzés jegyzet, Letöltés: 2012.09.14. On-line:

[10] http://ttk.nyme.hu/migi/Gazdalkodasi_es_menedzsment/Documents/Oktat\%C3\%B320se g\%C3\%A9danyagok/Pint\%C3\%A9r\%20R\%C3\%B3bert\%20\%20\%C3\%89rt\%C3\%A9kter emt\%C5\%91\%20folyamatok\%20menedzsmentje/Beszerz\%C3\%A9s_jegyzet.pdf 
[11] Th. B. C. Poeiszm, W. F. van RAAIJ (1993), The quality of industrial relationships; an economic psychological viewpoint, Proceedings Annual Colloquium van de International Association for Research in Economic Psychology, Moskou, pp. 38-55.

[12] L. M. Rinehart, J. A. Eckert, R. B. Handfield, T. Jr. Page, T. Atkin (2004), An Assessment of Supplier - Customer Relationships, Journal of Business Logistics, Vol. 25 (1), pp. 25-62.

[13] E. G. Smit, A. E. Bronner, M. E. Tolboom (2007), Relationship Quality and Its Value For Personal Contact; in Journal of Business Research 60(6), 2007, pp. 627-633.

[14] Sung Ho Ha, Eun Kyoung Kwon, Jong Sik Jin, Hyun Sun Park (2009), Single and Multiple Sourcing in the Auto-Manufacturing Industry, International Journal of Mechanical, Aerospace, Industrial, Mechatronic and Manufacturing Engineering, Vol:3, No:8, pp. Letöltés: 2016.02.23. On-line: http://waset.org/publications/1714/single-and-multiplesourcing-in-the-auto-manufacturing-industry

[15] L. Szarka (2002), Beszállítói ismeretek, Főiskolai jegyzet Dunaújvárosi Főiskola, Dunaújváros, (Hivatkozott mű: Szegedi Zoltán: Logisztika menedzsereknek, Kossuth, Budapest, 1998) Letöltés: 2012.11.12.

[16] On-line:http://www.vallalkozni.hu/ujpr/downloads/beszallitoi.htm\#_Toc14770848

[17] Z. Szegedi, J. Prezenszki (2003), Logisztika-menedzsment, Kossuth Kiadó, Budapest, p. 452.

[18] P. Ulkuniemi (2003), Purchasing software components at the dawn of market, Department of Marketing, University of Oulu, Oulun Yliopisto, Oulu, pp.69-72.

[19] R. Wise, D. Morrison (2000), Beyond the exchange: the future of B2B, Harvard Business Review (Nov-Dec), pp. 86-96. 